\title{
PERANAN HUKUM DALAM PENGELOLAAN SUMBER DAYA ALAM SKALA DESA OLEH BADAN USAHA MILIK DESA (BUMDES) DALAM MENINGKATKAN KESEJAHTERAAN MASYARAKAT DESA
}

\author{
(The Role of Law on Village Natural Resources Management by Village Owned Enterprise (BUMDES) \\ to Increase Village Society Welfare)
}

\author{
Agus Surono \\ Fakultas Hukum Universitas Al Azhar Indonesia \\ Jl. Sisingamangaraja Kebayoran Baru, Jakarta Selatan \\ Email: surono_uai@yahoo.com
}

Naskah diterima: 21 Agustus 2017; revisi: 13 November 2017; disetujui: 15 November 2017

\begin{abstract}
Abstrak
Kewenangan yang diberikan UU No. 6 Tahun 2014 tentang Desa memberikan landasan bagi desa untuk mengelola dan mengatur sumber daya alam skala desa baik yang berada di wilayah pantai maupun wilayah pegunungan. Dalam UU Desa tersebut memberikan peluang bagi desa untuk mengelola sumber daya alam melalui Badan Usaha Milik Desa (BUMDesa), sehingga desa benar-benar mempunyai kemandirian dalam mengelola sumber daya alam skala desa. Melalui pendekatan yuridis normatif, penelitian ini mengkaji bagaimanakah pengelolaan sumber daya alam skala desa menurut UU No. 6 Tahun 2014 tentang Desa? Kemudian, bagaimanakah peranan hukum dalam pengelolaan sumber daya alam skala desa oleh BUMDesa dalam meningkatkan kesejahteraan masyarakat di desa? Dan, bagaimanakah konsep pengelolaan BUMDesa dalam meningkatkan kesejahteraan masyarakat? Hasil penelitian menunjukan adanya pengaturan dalam berbagai peraturan perundang-undangan terkait dengan pengelolaan sumber daya alam skala desa oleh BUMDesa dan konsep pengelolaan sumber daya alam skala desa telah sejalan dan sesuai dengan sila kelima Pancasila yaitu "keadilan sosial bagi seluruh rakyat Indonesia", namun masih perlu dilakukan pengawasan oleh pihak-pihak terkait sesuai kewenangan baik Pemerintah Pusat maupun Pemerintah Daerah, sehingga pemenuhan hak desa atas sumber daya alam skala desa benar-benar dapat terwujud. Oleh sebab itu perlu diatur ketentuan teknis untuk melakukan monitoring dan evaluasi serta melakukan pembinaan terhadap desa.
\end{abstract}

Kata Kunci: peranan hukum, sumber daya alam, desa

\begin{abstract}
The authority given by Law Number 6 Year 2014 on Village give basis for Village to manage and maintain village-scale natural resources in both the coastal and mountainous areas. The law also give opportunity for Village to manage the natural resources through Village Owned Enterprise (BUMDes) so that there is independence in managing the village-scale natural resources. Through juridical normative approach, this research examines the management of village-scale natural resources refers to Law Number 6 Year 2017 on Village and the rola of law in village-scale natural resources management by the BUMDes in enhancing the Village Society Welfare and how the concept to do it. The research result shows that the regulation of the village-scale natural resources management by BUMdes through many regulations is in line with the $5^{\text {th }}$ Principles of Pancasila, "Social Justice for All the People of Indonesia". However, supervision is still needed to be conducted by relevant parties in accordance with the authority of both the Central Government As well as the Regional Government, so the implementation of village rights on village-scale natural resources can actually being realized. Therefore some technical need in monitoring, evaluating, and supervising the village are needed to be regulated.
\end{abstract}

Keywords: role of law, natural resources, village 


\section{A. Pendahuluan}

Dengan telah diundangkannya UU Nomor 6 Tahun 2014 tentang Desa (UU Desa) memberikan harapan baru bagi Indonesia, karena desa diharapkan dapat meningkatkan roda perekenomian negara melalui pengelolaan sumber daya alam skala desa. Berbeda dengan UU Nomor 23 Tahun 2014 tentang Pemerintahan Daerah, UU Desa mengembangkan cara pandang yang berbeda dan konsep baru terkait tentang desa dan tata kelola desa. UU Desa tersebut memberikan pengakuan dan penghormatan atas desa dengan keberagamannya, serta memberikan kejelasan status dan kepastian hukum atas desa dalam sistem ketatanegaraan Republik Indonesia. UU Desa ini menegaskan tentang: a) penyelenggaraan pemerintah desa; b) pelaksanaan pembangunan; c) pembinaan kemasyarakatan; dan d) pemberdayaan masyarakat berdasarkan Pancasila, UndangUndang Dasar 1945, Negara Kesatuan Republik Indonesia, dan Bhinneka Tunggal Ika.

Salah satu program yang dicanangkan dalam Nawacita dan amanah dari Rencana Pembangunan Jangka Menengah Nasional (RPJMN) Periode 2015-2019 adalah membangun Indonesia dari pinggiran dengan memperkuat daerah-daerah hingga sampai pada pemerintahan dan masyarakat di desa. Selanjutnya sasaran, arah kebijakan dan strategi pembangunan desa dalam RPJMN 2015-2019 tertuang sebagai berikut: sasaran pembangunan desa, arah kebijakan dan strategi pembangunan desa, arah kebijakan dan strategi pembangunan kawasan desa, arah kebijakan dan strategi tata pemerintahan desa, serta arah kebijakan dan strategi pengawalan implementasi UU Desa.
Dalam ketentuan UU Desa tersebut, desa mempunyai kewenangan sebagai berikut: ${ }^{1}$ kewenangan berdasarkan hak asalusul diberikan, kewenangan lokal berskala desa, kewenangan sesuai tugas pemerintah, pemerintah daerah provinsi, atau pemerintah daerah kabupaten/kota, dan kewenangan lain yang ditugaskan oleh Pemerintah, Pemerintah Daerah Provinsi. Selanjutnya kewenangan yang ada pada UU Desa tersebut memberikan landasan bagi desa untuk mengelola dan mengatur sumber daya alam skala desa seperti sektor kehutanan, perkebunan, pertambangan dan sumber daya alam lainnya, termasuk juga dalam pengelolaan sektor wisata skala desa baik yang berada di wilayah pantai maupun wilayah pegunungan. Pengaturan sumber daya alam yang tersebar dalam berbagai peraturan perundang-undangan yang masih sangat sentralistik yaitu mengenai perizinannya sangat sentralistik, seringkali tumpang tindih dengan peraturan perundang-undangan tentang desa sebagaimana diatur dalam UU Desa.

Dalam UU Desa tersebut memberikan peluang yang cukup signifikan bagi desa untuk mengelola sumber daya alam melalui Badan Usaha Milik Desa (BUMDesa) yang di berbagai desa yang ada di Indonesia sudah banyak sekali dikembangkan pola tersebut, sehingga desa benar-benar mempunyai kemandirian dalam mengelola sumber daya alamnya, terutama sumber daya alam skala desa. Di samping pengelolaan sumber daya alam skala desa oleh BUMDesa, dalam UU Desa juga memberikan kewenangan bagi desa untuk membuat peraturan perundang-undangan skala desa (Perdes) yang dapat dijadikan dasar hukum dalam pengelolaan sumber daya alam skala desa. 
Berdasarkan latar belakang tersebut di atas, maka penelitian ini membahas pengelolaan sumber daya alam skala desa menurut UU Desa dan peranan hukum dalam pengelolaan sumber daya alam skala desa oleh BUMDesa serta konsep pengelolaan BUMDesa dalam meningkatkan kesejahteraan masyarakat.

\section{B. Metode Penelitian}

Metode penelitian yang digunakan dalam penelitian ini adalah metode penelitian hukum yuridis normatif. Metode penelitian hukum normatif pada dasarnya meneliti kaidahkaidah hukum dan asas-asas hukum, menelaah permasalahan hukum yang dikemukakan dengan berpedoman pada data sekunder yaitu: bahan hukum primer, sekunder dan tersier. Bahan hukum primer yang dimaksud adalah UUD RI 1945, UU Desa, undang-undang yang relevan lainnya, peraturan pemerintah dan peraturan pelaksanaan lainnya yang relevan dengan judul artikel ini. Selanjutnya penulis dalam penyusunan artikel ini juga menggunakan bahan hukum sekunder yaitu doktrin, pendapat ahli, hasil karya ilmiah dalam berbagai jurnal ilmiah yang terkait dengan pengelolaan sumber daya alam skala desa dan juga terkait dengan kewenangan desa dalam mengelola sumber daya alam. Data yang terkumpul di atas yang berasal dari data sekunder, baik dari berbagai peraturan perundang-undangan, buku-buku dari berbagai literatur, juga penulusuran melalui jurnal-jurnal ilmiah, maupun yang lainnya, kemudian dilakukan analisis dengan menggunakan metode analisis kualitatif.

\section{Pembahasan}

\section{Pengelolaan Sumber Daya Alam Skala Desa Menurut UU No. 6 Tahun 2014 tentang Desa}

Menurut Pasal 18 UU Desa, kewenangan desa meliputi kewenangan di bidang penyelenggaraan pemerintahan desa, pelaksanaan pembangunan desa, pembinaan kemasyarakatan desa, dan pemberdayaan masyarakat desa berdasarkan prakarsa masyarakat, hak asal-usul, dan adat istiadat desa. Selanjutnya Pasal 19 UU Desa mengatur kewenangan desa yang meliputi kewenangan berdasarkan hak asal-usul, kewenangan lokal berskala desa, kewenangan yang ditugaskan oleh pemerintah, pemerintah daerah provinsi, atau pemerintah daerah kabupaten/kota; dan kewenangan lain yang ditugaskan oleh pemerintah, pemerintah daerah provinsi, atau pemerintah kabupaten/kota.

Berdasarkan kewenangan tersebut, desa mempunyai hak untuk melaksanakan pembangunan dengan memanfaatkan potensi sumber daya alam, termasuk sektor kehutanan di desa. Hak desa atas sumber daya alam, juga diatur dan dipertegas pada Pasal 371 ayat (2) UU No. 23 Tahun 2014 tentang Pemerintahan Daerah, yaitu bahwa desa mempunyai kewenangan sesuai dengan ketentuan peraturan perundang-undangan mengenai desa.

Asas-asas pengaturan desa sebagaimana dinyatakan dalam ketentuan Pasal 3 huruf a dan b UU Desa memiliki dua asas yang sangat penting yaitu²: rekognisi, yaitu pengakuan

2 Direktorat Pemberdayaan Masyarakat Desa, Dirjen. Pembangunan dan Pemberdayaan Masyarakat Desa, Panduan Pelatih: Pelatihan Masyarakat Tentang Advokasi Desa, Kementerian Desa, Pembangunan Daerah Tertinggal dan Transmigrasi, (2015), hlm. 60. 
terhadap hak asal-usul dan subsidiaritas, yaitu penetapan kewenangan berskala lokal dan pengambilan secara lokal untuk kepentingan masyarakat desa. Dikatakan penting karena kedua asas tersebut selain menjadi dasar bagi asas-asas yang lain, kedua asas tersebut juga ditegaskan kembali sebagai kewenangan desa, sebagaimana ketentuan Pasal 19 UU Desa. Oleh karena itu maka kedua asas tersebut dapat dikatakan sebagai dua asas dalam subtansi UU Desa, dan penting untuk dipahami secara khusus. Asas rekognisi ini berkaitan erat dengan definisi tentang desa sebagaimana diatur dalam Pasal 1 angka 1 UU Desa, yaitu bahwa desa"... mengatur dan mengurus berdasarkan prakarsa masyarakat, hak asal-usul, dan atau hak tradisional yang diakui dan dihormati dalam sistem pemerintahan NKRI." Rekognisi merupakan asas yang relevan dalam konteks desa sebagai kesatuan masyarakat hukum yang eksis dan memiliki hak asal-usul di mana masing-masing desa memiliki keragaman sesuai dengan konteksnya. ${ }^{3}$

Sedangkan asas subsidiaritas ditegaskan dalam Pasal 19 huruf b UU Desa, "Kewenangan Desa meliputi: ... b) kewenangan lokal berskala desa .....". Adanya kewenangan lokal merupakan konsekuensi adanya pengakuan desa sebagai kesatuan masyarakat hukum yang memiliki hak asal-usul. Adapun makna asas subsidiaritas adalah sebagai berikut ${ }^{4}$ : a) Penggunaan kewenangan dan pengambilan keputusan tentang kepentingan masyarakat setempat kepada desa; b) Negara menetapkan kewenangan lokal berskala desa menjadi kewenangan desa melalui tanpa melalui mekanisme delegasi maupun pelimpahan urusan/wewenang dari kabupaten/kota; dan c) Pemerintah melakukan dukungan dan fasilitasi terhadap desa dalam mengembangkan prakarsa dalam menyusun dan menetapkan kewenangan lokal berskala desa.

Dalam Buku I RPJMN Periode 2015-2019 dikatakan bahwa pola membangun Indonesia harus dilakukan melalui pinggiran dengan memperkuat daerah-daerah dan desa dalam kerangka negara kesatuan. Dalam kerangka tersebut, pembangunan desa dan kawasan perdesaan dilakukan melalui upaya mengurangi kesenjangan antara desa dan kota dengan mempercepat pembangunan desa-desa mandiri serta membangun keterkaitan ekonomi lokal antara desa dan kota melalui pembangunan kawasan perdesaan. ${ }^{5}$

Arah dan kebijakan ini, merupakan program yang harus menjadi fokus perhatian bagi pemerintah, pemerintah provinsi dan kabupaten/kota dalam melaksanakan pembangunan desa. Untuk mewujudkan hal ini, pemerintah desa dapat menciptakan inovasi dan kreativitas untuk mampu memanfaatkan dan mengelola potensi Sumber Daya Alam (SDA) skala desa secara berkelanjutan, sehingga diharapkan dapat meningkatkan kesejahteraan masyarakat desa. Kerangka hukum perlindungan hak desa atas sumber daya alam sektor kehutanan skala desa antara lain dapat diatur dalam peraturan perundang-undangan sebagai berikut ${ }^{6}$ :

Ibid., hlm. 67.

Ibid., hlm. 68-69.

Boni Kurniawan, Desa Mandiri, Desa Membangun, (Jakarta: Kementerian Desa, Pembangunan Daerah Tertinggal, dan Transmigrasi Republik Indonesia, 2015), hlm. 35.

$6 \quad$ Ibid., hlm. 45-46. 
Pertama, UUD RI Tahun 1945. Desa memiliki hak asal-usul dan hak tradisional dalam mengatur dan mengurus kepentingan masyarakat dan berperan mewujudkan cita-cita kemerdekaan menuju masyarakat yang adil, makmur, dan sejahtera. Hak tersebut dijamin dalam Pasal 18 ayat (7) dan Pasal 18B ayat (2) UUD NRI Tahun 1945. Selanjutnya terkait dengan pemanfaatan sumber daya alam sebagaimana ketentuan dalam Pasal 33 ayat (3) UUD NRI 1945, dinyatakan bahwa: "Bumi dan air dan kekayaan alam yang terkandung di dalamnya dikuasai oleh negara dan dipergunakan untuk sebesarsebesar kemakmuran rakyat." Ketentuan dalam Pasal 33 ayat (3) UUD 1945 tersebut, menjadikan dasar kebijakan Negara untuk mengatur penguasaan, pemilikan, penggunaan dan pemanfaatan sumber daya alam berupa tanah, di mana Negara berkewajiban untuk: 1) Bahwa segala bentuk pemanfaatan bumi dan air serta hasil yang didapat di dalamnya (kekayaan alam), harus secara nyata meningkatkan kemakmuran dan kesejahteraan masyarakat; 2) Melindungi dan menjamin segala hak-hak rakyat yang terdapat di dalam atau diatas bumi dan air yang dapat dihasilkan secara langsung oleh rakyat; 3) Mencegah agar rakyat tidak kehilangan atau kesempatan hak atas bumi, air dan isinya; 4) Berhak untuk menguasai dan mengelola tanah.

Kedua, UU No. 23 Tahun 2014 tentang Pemerintahan Daerah. Pemerintah melalui Undang-Undang Nomor 2 Tahun 2015 tentang Penetapan Peraturan Pemerintah Pengganti Undang-Undang Nomor 2 Tahun 2014 tentang Perubahan Atas Undang-Undang Nomor 23 Tahun 2014 tentang Pemerintahan Daerah Menjadi Undang-Undang, memberikan kewenangan desa atas sumber daya alam juga diatur dan dipertegas pada Pasal 371 ayat (2)
Undang-Undang Nomor 23 tahun 2014 tentang Pemerintahan Daerah, yaitu Desa mempunyai kewenangan sesuai dengan ketentuan peraturan perundang-undangan mengenai Desa.

Ketiga, UU No. 6 Tahun 2014 tentang Desa. Menurut Pasal 18 UU Desa, kewenangan desa meliputikewenangan dibidang penyelenggaraan pemerintahan desa, pelaksanaan pembangunan desa, pembinaan kemasyarakatan desa, dan pemberdayaan masyarakat desa berdasarkan prakarsa masyarakat, hak asal-usul, dan adatistiadat desa. Selanjutnya menurut Pasal 19 UU Desa, kewenangan desa meliputi: kewenangan berdasarkan hak asal-usul, kewenangan lokal berskala desa, kewenangan yang ditugaskan oleh pemerintah, pemerintah daerah provinsi, atau pemerintah daerah kabupaten/kota; dan kewenangan lain yang ditugaskan oleh pemerintah, pemerintah daerah provinsi, atau pemerintah kabupaten/kota.

Berdasarkan kewenangan yang diamanatkan dalam peraturan perundangan di atas, memberikan kewenangan kepada desa untuk mampu melaksanakan pembangunan desa dan kawasan perdesaaan dengan memanfaatkan potensi sumber daya alam di desa secara berkelanjutan, termasuk hak atas sumber daya alam baik sektor kehutanan, pertambangan, pertanian, perkebunan, serta sektor wisata dalam skala desa. Pengaturan tersebut bertujuan untuk menciptakan sumber mata pencaharian di desa melalui pemanfataan sumber daya alam skala desa guna meningkatkan kesejahteraan masyarakat.

Selanjutnya Pasal 78 ayat (1) menyatakan bahwa "Pembangunan Desa bertujuan meningkatkan kesejahteraan masyarakat Desa dan kualitas hidup manusia serta penanggulangan kemiskinan melalui pemenuhan kebutuhan dasar, pembangunan 
sarana dan prasarana Desa, pengembangan potensi ekonomi lokal, serta pemanfaatan sumber daya alam dan lingkungan secara berkelanjutan.

Keempat, UU No. 41 Tahun 1999 tentang Kehutanan sebagaimana telah diubah dengan UU No. 19 Tahun 2004 tentang Penetapan Peraturan Pemerintah Penganti UU No. 1 Tahun 2004 tentang Perubahan Atas UU No. 41 Tahun 1999 tentang Kehutanan Menjadi UndangUndang. Pasal 3 huruf e UU No. 41 Tahun 1999 menyatakan bahwa: "Penyelenggaraan kehutanan bertujuan untuk sebesar-besar kemakmuran rakyat yang berkeadilan dan berkelanjutan dengan: e. menjamin distribusi manfaat yang berkeadilan dan berkelanjutan. Adapun Pasal 23 UU No. 41 Tahun 1999 menyatakan bahwa: "Pemanfaatan hutan sebagaimana dimaksud dalam Pasal 21 huruf $b$, bertujuan untuk memperoleh manfaat yang optimal bagi kesejahteraan seluruh masyarakat secara berkeadilan dengan tetap menjaga kelestariannya. Mengenai hak desa dalam pengelolaan sumber daya hutan skala desa sebagai pelaksanaan atas UU No. 41 Tahun 1999 tentang Kehutanan, maka Pemerintah telah menerbitkan Peraturan Menteri Kehutanan No: P.89/Menhut-II/2014 tentang Hutan Desa.

\section{Peranan Hukum Dalam Pengelolaan Sumber Daya Alam Skala Desa Oleh BUMDesa Untuk Meningkatkan Kesejahteraan Masyarakat Desa}

Kemandirian desa saat ini menjadi isu penting yang perlu diperhatikan secara lebih serius serta didiskusikan lebih mendalam. Pasalnya, sejak UU Desa disahkan, kebijakan utama tersebut adalah dengan adanya alokasi dana desa yang diperkirakan berkisar Rp. 800.000.000,(delapan ratus juta rupiah) sampai Rp. 1 Milyar per desa. Kebijakan desentralisasi fiskal ke desa ini menunjukkan bentuk keberpihakan yang besar dan progresif dari pemerinta pusat akan prioritas peningkatan pembangunan daerah dalam pelayanan masyarakat demi terwujudnya kesejahteraan masyarakat. Dana tersebut dapat digunakan sebagai modal pembangunan desa melalui BUMDesa sebagaimana ketentuan Pasal 87 s.d. Pasal 90 UU Desa dengan maksud untuk mendorong peningkatan skala ekonomi usaha produktif masyarakat desa, termasuk juga dalam pengelolaan sumber daya alam skala desa. ${ }^{7}$

Pemerintah desa merupakan lembaga perpanjangan pemerintah pusat yang memiliki peran strategis dalam pengaturan masyarakat desa/kelurahan dan keberhasilan pembangunan. Sebab pemerintah desa memiliki peran yang sangat signifikan dalam pengelolaan sumber daya alam skala desa, mengingat lokasi sumber daya alam tersebut secara administratif berada di desa. Tugas utama yang diemban oleh pemerintah desa antara lain memberikan pelayanan sosial yang baik sehingga membawa warganya pada kehidupan yang sejahtera, rasa tenteram dan berkeadilan.

Salah satu instrumen penting dalam mewujudkan desa yang sejahtera terutama dalam pengelolaan sumber daya alam skala desa adalah melalui pembentukan BUMDesa. BUMDesa dapat dijadikan sebagai wadah warga setempat dalam melakukan kemandirian dan pemberdayaan desa terhadap sumber daya alam skala desa baik dalam bidang

Fajar Sidik, "Menggali Potensi Lokal Mewujudkan Kemandirian Desa”, Yogyakarta: Jurnal Kebijakan dan Administrasi Publik, Vol. 19, No. 2, JKAP UGM, November (2015), hlm. 116. 
pertanian, perikanan, potensi wisata pantai dan pegunungan, pertambangan, perkebunan dan sektor sumber daya alam lainnya sebab desa dipandang sebagai sebuah kesatuan masyarakat hukum atau badan hukum publik juga memiliki kewenangan meskipun tidak luas kewenangan yang dimiliki oleh pemerintah daerah. Kewenangan desa adalah hak desa untuk mengatur, mengurus, dan bertanggungjawab atas urusan pemerintah dan kepentingan masyarakat setempat. ${ }^{8}$

Pembangunan desa dan kawasan perdesaan secara komprehensif merupakan faktor penting bagi pembangunan daerah, pengentasan kemiskinan, dan pengurangan kesenjangan antarwilayah. Perkembangan jumlah desa di Indonesia meningkat pesat, dari 72.944 desa pada tahun 2012 menjadi 74.093 desa tahun 2014. Sayangnya jumlah yang selalu meningkat ini tidak diikuti dengan peningkatan kesejahteraan masyarakat. Keterisolasian wilayah karena keterbatasan akses, baik transportasi, telekomunikasi, pendidikan, kesehatan, maupun permukiman, terutama di desa-desa di kawasan perbatasan, daerah tertinggal, dan pulau-pulau kecil terluar, menjadi penyebab tingginya tingkat kemiskinan di desa. ${ }^{9}$

Isu-isu strategis pembangunan desa dan kawasan perdesaan yang perlu diselesaikan adalah $^{10}:$ 1) tingkat kesejahteraan dan kualitas hidup masyarakat di perdesaan yang masih rendah; 2) ketersediaan sarana dan prasarana fisik maupun non-fisik di desa dan kawasan perdesaan yang belum memadai; 3) ketidakberdayaan masyarakat perdesaan akibat faktor ekonomi maupun non ekonomi; 4) pelaksanaan tata kelola pemerintahan Desa yang memerlukan penyesuaian dengan amanat UU Desa; dan 5) kualitas lingkungan hidup masyarakat desa memburuk dan sumber pangan yang terancam berkurang.

Pengembangan potensi ekonomi lokal desa yang belum optimal akibat kurangnya akses dan modal dalam proses produksi, pengolahan, maupun pemasaran hasil produksi masyarakat desa. Sasaran pembangunan desa dan kawasan perdesaan adalah mengurangi jumlah desa tertinggal sampai 5000 desa dan meningkatkan jumlah desa mandiri sedikitnya 2000 desa.

Arah kebijakan pembangunan desa dan kawasan perdesaan tahun 20152019 adalah sebagai berikut ${ }^{11}$ : Pertama, Penguatan Pemerintahan Desa, melalui pengembangan kapasitas dan pendampingan aparatur pemerintah desa dan kelembagaan pemerintahan desa secara berkelanjutan;

Kedua, Pembangunan Desa, melalui pemenuhan standar pelayanan minimum desa sesuai dengan kondisi geografis desa, penanggulangan kemiskinan dan pengembangan usaha ekonomi masyarakat desa, melalui penataan dan penguatan BUMDesa; Ketiga, Pembangunan Kawasan Perdesaan, melalui pengelolaan sumber daya alam dan lingkungan hidup berkelanjutan dan penataan ruang kawasan perdesaan, pengembangan ekonomi kawasan perdesaan untuk mendorong keterkaitan desakota; Keempat, Pengawalan implementasi UU Desa secara sistematis, konsisten, dan berkelanjutan melalui koordinasi, fasilitasi, supervisi, dan pendampingan.

Ibid., hlm. 119.

Sutoro Eko, Desa Membangun Indonesia, (Yogyakarta: FPPD, 2014), hlm. 23.

10 Ibid., hlm. 25-26.

11 Ibid., hlm. 27. 
Peranan hukum dalam pengelolaan sumber daya alam skala desa dalam mewujudkan kesejahteraan masyarakat desa dapat ditunjukkan dalam beberapa peraturan sebagai berikut:

Pertama, Perpres Nomor 2 Tahun 2015 tentang RPJM 2015-2019. Ketentuan Perpres No. 2 Tahun 2015 dalam poin 1 (iii) menyatakan "Menyiapkan dan melaksanakan kebijakan untuk membebaskan desa dari kantong-kantong hutan dan perkebunan." Peraturan Presiden tersebut merupakan kebijakan Pemerintah agar masyarakat desa di sekitar kawasan hutan dan kawasan perkebunan dapat memanfaatkan sumber daya hutan non kayu dan juga memanfaatkan kawasan perkebunan dengan cara sistem tumpang sari untuk menanam tanaman pangan seperti singkong, jagung dan lainnya. Sehingga keberadaan kawasan hutan dan juga kawasan perkebunan bagi masyarakat setempat benar-benar memberikan manfaat dalam mewujudkan kesejahteraan masyarakat.

\section{Kedua, UU Nomor 6 Tahun 2014 tentang}

Desa. Pasal 1 butir 9 menyatakan bahwa "Kawasan Perdesaan adalah kawasan yang mempunyai kegiatan utama pertanian, termasuk pengelolaan sumber daya alam dengan susunan fungsi kawasan sebagai tempat permukiman perdesaan, pelayanan jasa pemerintahan, pelayanan sosial, dan kegiatan ekonomi". Selanjutnya Pasal 78 ayat (1) dinyatakan bahwa "Pembangunan Desa bertujuan meningkatkan kesejahteraan masyarakat Desa dan kualitas hidup manusia serta penanggulangan kemiskinan melalui pemenuhan kebutuhan dasar, pembangunan sarana dan prasarana Desa, pengembangan potensi ekonomi lokal, serta pemanfaatan sumber daya alam dan lingkungan secara berkelanjutan".
Kemudian Pasal 1 butir 6 "Badan Usaha Milik Desa (BUM Desa) adalah badan usaha yang seluruh atau sebagian besar modalnya dimiliki oleh desa melalui penyertaan secara langsung yang berasal dari kekayaan desa yang dipisahkan guna mengelola aset, jasa pelayanan dan usaha lainnya untuk sebesar-besarnya kesejahteraan masyarakat desa". Adapun Pasal 1 butir 9 menyatakan bahwa kategori dari kawasan pedesaan adalah kawasan yang mempunyai kegiatan utama pertanian, termasuk di dalamnya adalah pengelolaan sumber daya alam.

Ketentuan Pasal 4 UU Desa yang menjelaskan bahwa Desa diperkenankan untuk membuat suatu peraturan desa dalam rangka memajukan perekonomian masyarakat desa serta mengatasi kesenjangan pembangunan nasional, dalam hal ini tentu saja bagaimana perangkat desa mampu membuka pintu bagi peluang investor untuk masuk dalam pengelolaan BUM Desa dalam rangka pengelolaan sumber daya alam skala desa.

Berdasarkan ketentuan yang terdapat dalam UU Desa tersebut, memberikan landasan hukum bahwa masyarakat desa mempunyai hak atas sumber daya alam untuk mengelola sumber daya alam baik kegiatan seperti sektor agrowisata, ekowisata, serta sektor pertanian yang tujuannya adalah dalam rangka mewujudkan kesejahteraan masyarakat desa. Potensi-potensi sumber daya alam di masingmasing desa, di berbagai wilayah Indonesia sangat berbeda-beda, oleh karenanya masingmasing desa harus dapat mengembangkan potensi desanya masing-masing. Selanjutnya dalam pengelolaan sumber daya alam yang ada di desa sesuai potensi masing-masing desa, harus dapat dikelola secara profesional melalui Badan Usaha Milik Desa (BUMDes) yang diatur 


\section{R duknal HTSVINDING}

Media Pembinaan Hukum Nasional

dalam Peraturan Desa sebagai landasan hukum dalam pengelolaan sumber daya alam di desa oleh BUMDes.

Ketiga, UU Nomor 41 Tahun 1999 tentang Kehutanan. Perencanaan kehutanan sebagaimana dimaksud dalam Pasal 10 ayat (2) huruf a, meliputi: a. inventarisasi hutan; b. pengukuhan kawasan hutan; c. penatagunaan kawasan hutan; d. pembentukan wilayah pengelolaan hutan; dan e. penyusunan rencana kehutanan. Berdasarkan ketentuan dalam UU Kehutanan tersebut, terkait perencanaan kehutanan yang menjadi kewenangan Pemerintah dalam hal ini Kementerian Kehutanan, juga memberikan landasan bahwa dalam pembentukan wilayah kehutanan dan juga penyusunan rencana kehutanan harus juga memperhatikan kepentingan masyarakat desa, khususnya terkait hak desa atas sumber daya alam skala desa sebagaimana amanat UU Desa.

Keempat, UU Nomor 39 Tahun 2014 tentang Perkebunan. Pasal 3 huruf a dinyatakan bahwa: "Penyelenggaraan perkebunan bertujuan untuk meningkatkan kesejahteraan dan kemakmuran rakyat". Selanjutnya Pasal 51 ayat (1) dan ayat

(2) dinyatakan sebagai berikut:

(1) Pemerintah Pusat dan Pemerintah Daerah sesuai dengan kewenangannya berkewajiban menyelenggarakan pemberdayaan usaha perkebunan.

(2) Pemberdayaan usaha perkebunan sebagaimana dimaksud pada ayat (1) dapat dilakukan dengan melibatkan masyarakat.

Adapun ketentuan Pasal 57 ayat (1) menyatakan bahwa: "Untuk pemberdayaan usaha perkebunan, Perusahaan Perkebunan melakukan kemitraan usaha perkebunan yang saling menguntungkan, saling menghargai, saling bertanggungjawab, serta saling
Volume 6, Nomor 3, Desember 2017

memperkuat dan saling ketergantungan dengan pekebun, karyawan, dan masyarakat di sekitar perkebunan."

Berdasarkan ketentuan dalam UU Perkebunan tersebut memberikan landasan bahwa dalam penyelenggaraan usaha perkebunan bertujuan untuk meningkatkan kesejehtaraan masyarakat, termasuk juga bagi masyarakat sekitar kawasan perkebunan melalui pola kemitraan usaha perkebunan. Dengan melibatkan masyarakat tersebut, maka diharapkan tujuan usaha perkebunan yang salah satunya untuk mewujudkan kesejahteraan masyarakat dapat terwujud sesuai dengan harapan masyarakat. Sehingga dengan demikian keberadaan kawasan perkebunan di desa-desa mampu mewujudkan kesejahteraan masyarakat.

Kelima, PP Nomor 43 tahun 2014 tentang Peraturan Pelaksanaan UU Desa sebagaimana telah diubah dengan PP Nomor 47 Tahun 2015 tentang Perubahan Atas Peraturan Pemerintah Nomor 43 Tahun 2014 tentang Peraturan Pelaksanaan Undang-Undang Nomor 6 Tahun 2014 tentang Desa. Pasal 123 ayat (2) dinyatakan bahwa "Pembangunan kawasan perdesaan terdiri atas: a. penyusunan rencana tata ruang kawasan perdesaan secara partisipatif; $b$. pengembangan pusat pertumbuhan antardesa secara terpadu; c. penguatan kapasitas masyarakat; d. kelembagaan dan kemitraan ekonomi; dan e. pembangunan infrastruktur antarperdesaan".

Pasal 110 ayat 2 dinyatakan bahwa: “Pengelolaan kekayaan milik Desa diatur dengan peraturan Desa dengan berpedoman pada peraturan menteri yang menyelenggarakan urusan pemerintahan di bidang pemerintahan dalam negeri". Adapun Pasal 111 ayat (1) dinyatakan bahwa: "Pengelolaan kekayaan milik 
Desa yang berkaitan dengan penambahan dan pelepasan aset ditetapkan dengan peraturan Desa sesuai dengan kesepakatan musyawarah Desa". Pasal 111 ayat (2) menyatakan: "Kekayaan milik Pemerintah dan pemerintah daerah berskala lokal Desa dapat dihibahkan sesuai dengan ketentuan peraturan perundangundangan".

Berdasarkan ketentuan tersebut memberikan landasan hukum bahwa pembangunan kawasan perdesaan dapat dilakukan antara lain dengan penguatan kelembagaandankemitraanekonomi.Penguatan kelembagaan dapat dilakukan dengan cara membentuk BUMDes dengan terlebih dahulu dibuat aturan dalam bentuk Peraturan Desa (Perdes) yang mengatur tentang kelembagaan pembangunan kawasan perdesaan, khususnya terkait dalam pengelolaan sumber daya alam di desa. Selanjutnya untuk mengatasi adanya keterbatasan modal, maka pemerintah desa dapat melakukan pola kemitraan dengan bekerjasama dengan mitra terkait dengan diatur melalui Peraturan Desa. Hal ini dilakukan untuk menghindari permasalahan di kemudian hari terkait dengan persoalan manajemen dalam mengembangkan sumber ekonomi masyarakat desa untuk mewujudkan kesejahteraan masyarakat desa.

\section{Keenam, Permendes PDTT Nomor}

\section{Tahun 2015 tentang Pedoman Tata Tertib} dan Mekanise Pengambilan Keputusan Musyawarah Desa. Pasal 1 butir 2 menyatakan bahwa: "Musyawarah Desa atau yang disebut dengan nama lain adalah musyawarah antara Badan Permusyawaratan Desa, Pemerintah Desa, dan unsur masyarakat yang diselenggarakan oleh Badan Permusyawaratan Desa untuk menyepakati hal yang bersifat strategis". Selanjutnya Pasal 2 ayat (1) berbunyi:
"Musyawarah Desa atau yang disebut dengan nama lain adalah musyawarah antara Badan Permusyawaratan Desa, Pemerintah Desa, dan unsur masyarakat yang diselenggarakan oleh Badan Permusyawaratan Desa untuk menyepakati hal yang bersifat strategis". Kemudian Pasal 2 ayat (2) menyatakan bahwa: "Hal yang bersifat strategis sebagaimana dimaksud pada ayat (1) meliputi: a. penataan Desa; b. perencanaan Desa; c. kerjasama Desa; d. rencana investasi yang masuk ke Desa; e. pembentukan BUMDesa; f. penambahan dan pelepasan aset Desa; dan g. kejadian luar biasa".

Berdasarkan ketentuan tersebut memberikan landasan bagi masyarakat desa terkait dengan musyawarah desa dalam rangka pembentukan Badan Usaha Milik Desa (BUMDes) dan juga dalam melakukan investasi terhadap pengelolaan atas potensi sumber daya alam di desa, berikut tentang perencanaannya dan hal-hal yang sifatnya strategis dalam rangka melakukan pengelolaan sumber daya alam untuk mewujudkan kesejahteraan bagi masyarakat desa. Musyawarah desa tersebut harus dilakukan agar dalam pengelolaan potensi sumber daya alam yang ada di masing-masing desa yang mulai dari tahap perencanaan, pembentukan BUMDes, dan juga terkait dengan pola kemitraan terkait investasi pengelolaan sumber daya alam skala desa dapat dilaksanakan dengan baik guna mewujudkan kesejahteraan masyarakat desa.

\section{Konsep Pengelolaan BUMDesa Sesuai Tujuan Nasional Menurut Prinsip Keadilan Sosial Dalam Meningkatkan Kesejahteraan Masyarakat}

Konsep Negara kesejahteraan sebagaimana dimaksud dalam ketentuan Pasal 33 ayat (3) UUD RI Tahun 1945, menyebabkan negara 
mempunyai peran penting dalam mengatur dalam mewujudkan hak-hak masyarakat desa. Instrumen penting yang dapat digunakan oleh negara dalam menyelenggarakan fungsi reguleren termasuk dalam bidang agraria khususnya terhadap tanah, hutan, perkebunan, serta sumber daya alam lainnya adalah undangundang, dan ini merupakan aplikasi dari asas legalitas dalam konsep negara berdasar atas hukum. Konsep Negara Kesejahteraan dalam UUD 1945 pertama kali diadopsi oleh Muhamad Hatta, ${ }^{12}$ dan salah satu kebijakan yang didorong terkait konsep negara kesejahteraan yaitu kebijakan pengelolaan sumber daya alam di Indonesia, termasuk juga di dalamnya sumber daya agraria, dengan mengacu pada ideologi penguasaan dan pemanfaatan sebagaimana tercermin dalam Pasal 33 ayat (3) UndangUndang Dasar 1945, ini menunjukkan bahwa negara menguasai kekayaan alam yang terkandung di dalamnya, namun penguasaan ini dibatasi yaitu harus dipergunakan untuk sebesarnya-besarnya kemakmuran rakyat. ${ }^{13}$ Campur tangan Pemerintah tersebut di atas menunjukkan bahwa Indonesia menganut konsep negara kesejahteraan (welfare state), sebagaimana dicetuskan oleh Beveridge. ${ }^{14}$ Selain konsep negara kesejahteraan sebagaimana diuraikan tersebut diatas juga sangat relevan adalah teori keadilan sosial sebagaimana dimaksud dalam sila kelima Pancasila yang menyatakan: "keadilan sosial bagi seluruh rakyat Indonesia". Makna seluruh rakyat Indonesia di sini termasuk juga adalah kesejahteraan bagi masyarakat desa, melalui hak desa untuk mengelola sumber daya alam skala desa yang dikelola oleh BUMDesa.

Pengaturan pengelolaan sumber daya alam skala desa oleh BUMDesa dalam mewujudkan kesejahteraan masyarakat desa antara lain dapat diuraikan sebagai berikut:

Pertama, Perpres Nomor 2 Tahun 2015 tentang RPJM 2015-2019. Poin 1 (v) Menyiapkan dan melaksanakan kebijakan-regulasi baru tentang shareholding antara pemerintah, investor, dan desa dalam pengelolaan sumber daya alam. Poin 1 (vi) Menjalankan programprogram investasi pembangunan perdesaan dengan pola shareholding melibatkan desa dan warga desa sebagai pemegang saham.

Kedua, UU Nomor 6 Tahun 2014 tentang Desa. Pasal 1 butir 6 "Badan Usaha Milik Desa (BUM Desa) adalah badan usaha yang seluruh atau sebagian besar modalnya dimiliki oleh desa melalui penyertaan secara langsung yang berasal dari kekayaan desa yang dipisahkan guna mengelola aset, jasa pelayanan dan usaha lainnya untuk sebesar-besarnya kesejahteraan masyarakat desa". Pasal 1 butir 9 menyatakan bahwa kategori dari kawasan pedesaan adalah kawasan yang mempunyai kegiatan utama pertanian, termasuk di dalamnya adalah pengelolaan sumber daya alam. Selanjutnya Pasal 4 UU Desa yang menjelaskan bahwa Desa

12 Jimly Asshiddiqie, Undang-Undang Dasar 1945: Konstitusi Negara Kesejahteraan dan Realitas Masa Depan, (Jakarta: Universitas Indonesia, 1998).

13 Muchsan, Hukum Administrasi Negara dan Peradilan, Administrasi Negara di Indonesia, (Jakarta: Liberti, 2003), hlm. 9.

14 Beveridge seorang anggota Parlemen Inggris dalam report-nya yang mengandung suatu program sosial, dengan perincian antara lain tentang meratakan pendapatan masyarakat, usulan kesejahteraan sosial, peluang kerja, pengawasan upah oleh Pemerintah dan usaha di bidang pendidikan. Muchtar Kusumaatmadja, Konsep-Konsep Hukum Dalam Pembangunan, (Bandung: PT. Alumni, 2002), hlm. 82. 
diperkenankan untuk membuat suatu peraturan desa dalam rangka memajukan perekonomian masyarakat desa serta mengatasi kesenjangan pembangunan nasional, dalam hal ini tentu saja bagaimana perangkat desa mampu membuka pintu bagi peluang investor untuk masuk dalam pengelolaan BUMDesa dalam rangka pengelolaan sumber daya alam skala desa.

Kemudian Pasal 26 menjelaskan apa yang menjadi tugas Kepala Desa yaitu salah satunya adalah melaksanakan pembangunan desa. Hal ini berarti bahwa sebagai salah satu bentuk pembangunan desa yang ditujukan dalam rangka meningkatkan kesejahteraan masyarakat desa maka kepala desa harus mampu secara mandiri menciptakan peluang terbukanya peluang bagi investor untuk masuk dan terlibat dalam pembangunan desa, salah satunya adalah melalui BUMDesa.

Pasal 78 ayat (1) menyatakan "Pembangunan Desa bertujuan meningkatkan kesejahteraan masyarakat Desa dan kualitas hidup manusia serta penanggulangan kemiskinan melalui pemenuhan kebutuhan dasar, pembangunan sarana dan prasarana Desa, pengembangan potensi ekonomi lokal, serta pemanfaatan sumber daya alam dan lingkungan secara berkelanjutan. Pasal 81 ayat (3) menyatakan "Pelaksanaan Pembangunan Desa sebagaimana dimaksud pada ayat (1) dilakukan dengan memanfaatkan kearifan lokal dan sumber daya alam Desa. Pasal 90 menyatakan "Pemerintah, Pemerintah Daerah Provinsi, Pemerintah Daerah Kabupaten/Kota, dan Pemerintah Desa mendorong perkembangan BUMDesa dengan:a) memberikan hibah dan/atau akses permodalan; b) melakukan pendampingan teknis dan akses ke pasar; dan c) memprioritaskan BUM Desa dalam pengelolaan sumber daya alam di Desa”.
Ketiga, PP Nomor 43 tahun 2014 tentang Peraturan Pelaksanaan UU Desa sebagaimana telah diubah dengan PP Nomor 47 Tahun 2015 tentang Perubahan Atas Peraturan Pemerintah Nomor 43 Tahun 2014 tentang Peraturan Pelaksanaan Undang-Undang Nomor 6 Tahun 2014 tentang Desa. Pasal 1 butir 7: "Badan Usaha Milik Desa, selanjutnya disebut BUMDesa, adalah badan usaha yang seluruh atau sebagian besar modalnya dimiliki oleh Desa melalui penyertaan secara langsung yang berasal dari kekayaan Desa yang dipisahkan guna mengelola aset, jasa pelayanan, dan usaha lainnya untuk sebesar-besarnya kesejahteraan masyarakat Desa". Pasal 132 ayat (1): "Desa dapat mendirikan BUMDesa", sedangkan Pasal 132 ayat (2): "Pendirian BUMDesa sebagaimana dimaksud pada ayat (1) dilakukan melalui musyawarah Desa dan ditetapkan dengan peraturan Desa". Pasal 132 ayat (3): "Organisasi pengelola BUM Desa terpisah dari organisasi Pemerintahan Desa". Pasal 132 ayat (4): "Organisasi pengelola BUMDesa sebagaimana dimaksud pada ayat (1) paling sedikit terdiri atas: a. penasihat; dan b. pelaksana operasional".

Pasal 135 ayat (1): "Modal awal BUMDesa bersumber dari APBDesa. Pasal 135 ayat (2): "Modal BUM Desa terdiri atas: a. penyertaan modal Desa; dan b. penyertaan modal masyarakat Desa." Pasal 135 ayat (3): "Kekayaan BUM Desa yang bersumber dari penyertaan Modal Desa sebagaimana dimaksud pada ayat (2) huruf a merupakan kekayaan Desa yang dipisahkan". Pasal 135 ayat (4): "Penyertaan modal Desa sebagaimana dimaksud pada ayat (2) huruf a berasal dari APBDesa." Pasal 135 ayat (5): "Pemerintah, pemerintah daerah provinsi, dan pemerintah daerah kabupaten/kota dapat memberikan bantuan kepada BUM Desa yang disalurkan melalui APBDesa." 
Pasal 137 ayat (2): "BUMDesa yang melakukan pinjaman harus mendapatkan persetujuan Pemerintah Desa". Pasal 137 ayat(3): "Pendirian, pengurusan, dan pengelolaan unit usaha BUM Desa sebagaimana dimaksud pada ayat (1) dilaksanakan sesuai dengan ketentuan peraturan perundang-undangan." Pasal 138 ayat (1): "Pelaksana operasional dalam pengurusan dan pengelolaan usaha Desa mewakili BUMDesa di dalam dan di luar pengadilan." Pasal 138 ayat (2): "Pelaksana operasional wajib melaporkan pertanggungjawaban pengurusan dan pengelolaan BUMDesa kepada kepala Desa secara berkala." Pasal 139: "Kerugian yang dialami oleh BUMDesa menjadi tanggung jawab pelaksana operasional BUMDesa". Pasal 140 ayat (1): "Kepailitan BUMDesa hanya dapat diajukan oleh kepala Desa". Pasal 140 ayat (2): "Kepailitan BUMDesa sebagaimana dimaksud pada ayat (1) dilaksanakan sesuai dengan mekanisme yang diatur dalam ketentuan peraturan perundang-undangan."

Keempat, Perpres Nomor 12 Tahun 2015 tentang Kementerian Desa, PDT, dan Transmigrasi. Pasal 9 menyatakan: "Direktorat Jenderal Pembangunan dan Pemberdayaan Masyarakat Desa mempunyai tugas menyelenggarakan perumusan dan pelaksanaan kebijakan di bidang pembinaan pengelolaan pelayanan sosial dasar, pengembangan usaha ekonomi desa, pendayagunaan sumber daya alam dan teknologi tepat guna, pembangunan sarana prasarana desa, dan pemberdayaan masyarakat desa sesuai ketentuan peraturan perundang-undangan".

Kelima, Permendagri Nomor 114 Tahun 2014 tentang Pedoman Pembangunan Desa. Pasal 69 ayat (1): "Kepala Desa mengutamakan pemanfaatan sumber daya manusia dan sumber daya alam yang ada di Desa serta mendayagunakan swadaya dan gotong-royong masyarakat sebagaimana dimaksud dalam Pasal 63 melalui mekanisme pembangunan Desa secara swakelola". Pasal 2 ayat (5): "Dalam rangka mengkoordinasikan pembangunan Desa sebagaimana dimaksud pada ayat (2), kepala desa dapat didampingi oleh tenaga pendamping profesional, kader pemberdayaan masyarakat Desa, dan/atau pihak ketiga. Pasal 3 Pembangunan desa sebagaimana dimaksud dalam Pasal 2 mencakup bidang penyelenggaraan pemerintahan Desa, pelaksanaan pembangunan Desa, pembinaan kemasyarakatan Desa dan pemberdayaan masyarakat Desa.

Pasal 6 ayat (1): "Rancangan RPJM Desa memuat visi dan misi kepala Desa, arah kebijakan pembangunan Desa, serta rencana kegiatan yang meliputi bidang penyelenggaraan Pemerintahan Desa, pelaksanaan pembangunan Desa, pembinaan kemasyarakatan Desa, dan pemberdayaan masyarakat Desa".

Pasal 6 ayat 3d: "Pengembangan usaha ekonomi produktif serta pembangunan, pemanfaatan dan pemeliharaan sarana dan prasarana ekonomi antara lain: 1. pasar Desa; 2. pembentukan dan pengembangan BUMDesa; 3. penguatan permodalan BUMDesa; 4 . pembibitan tanaman pangan; 5 . penggilingan padi; 6. lumbung Desa; 7. pembukaan lahan pertanian; 8. pengelolaan usaha hutan Desa; 9. kolam ikan dan pembenihan ikan; 10. kapal penangkap ikan; 11 . cold storage (gudang pendingin); 12. tempat pelelangan ikan; 13. tambak garam; 14. kandang ternak; 15 . instalasi biogas; 16. mesin pakan ternak; 17. sarana dan prasarana ekonomi lainnya sesuai kondisi Desa.

Pasal 65 ayat (1): "Pelaksana kegiatan mendayagunakan sumberdaya alam yang ada di Desa, sekurang-kurangnya melakukan: a. 
pendataan kebutuhan material/bahan yang diperlukan; b. penentuan material/bahan yang disediakan dari Desa; dan c. menentukan cara pengadaan material/bahan".

Keenam, Permendes PDTT Nomor 1 Tahun 2015 tentang Pedoman Kewenangan Berdasarkan Hak Asal-Usul dan Kewenangan Lokal Berskala Desa. Pasal 1 butir 2: "Kewenangan Desa adalah kewenangan yang dimiliki Desa meliputi kewenangan di bidang penyelenggaraan Pemerintahan Desa, pelaksanaan Pembangunan Desa, Pembinaan Kemasyarakatan Desa, dan Pemberdayaan Masyarakat Desa berdasarkan prakarsa masyarakat, hak asal-usul dan adat-istiadat Desa. Pasal 1 butir 4: "Kewenangan lokal berskala Desa adalah kewenangan untuk mengatur dan mengurus kepentingan masyarakat Desa yang telah dijalankan oleh Desa atau mampu dan efektif dijalankan oleh Desa atau yang muncul karena perkembangan Desa dan prakasa masyarakat Desa". Pasal 1 butir 10: "Pembangunan Desa adalah upaya peningkatan kualitas hidup dan kehidupan untuk sebesarbesarnya kesejahteraan masyarakat Desa".

Pasal 4: "Pemerintah, pemerintah provinsi, dan pemerintah kabupaten/kota harus mengakui, menghormati dan melindungi kewenangan berdasarkan hak asal usul sebagaimana dimaksud dalam Pasal 2. Pasal 8: "Kewenangan lokal berskala Desa di bidang pemerintahan Desa sebagaimana dimaksud dalam Pasal 7 huruf a antara lain meliputi:... I. penetapan BUMDesa."

Ketujuh, Permendes PDTT Nomor 2 Tahun 2015Tentang Pedoman Tata TertibdanMekanise Pengambilan Keputusan Musyawarah Desa. Pasal 82 ayat (1): “Pengelolaan sumber daya desa dapat dilakukan dengan cara kerjasama Desa dengan pihak ketiga melalui kegiatan investasi masuk Desa. Pasal 84 ayat (1): "Ruang lingkup kegiatan usaha ekonomi yang dapat dibiayai dengan dana investasi masuk Desa meliputi usaha yang dikelola oleh BUMDesa, dan/atau usaha perseorangan atau usaha kelompok masyarakat yang menimbulkan dampak positif atau negatif sebagaimana dimaksud dalam Pasal 83 ayat (3)". Pasal 84 ayat (2): "Jenis usaha ekonomi yang dibiayai oleh dana investasi meliputi antara lain : hutan, kebun, ternak, perikanan, agroindustri kerakyatan dan usahausaha ekonomi lainnya sesuai dengan kondisi obyektif Desa dan masyarakat Desa". Pasal 84 ayat (2): "Pola kerjasama Desa dengan pihak ketiga dalam rangka investasi masuk Desa adalah shareholding yang melibatkan desa dan warga Desa sebagai pemegang saham".

Pasal 87 ayat (1): "Rencana investasi masuk Desa dilakukan dengan cara membangun kerjasama desa dengan pihak ketiga untuk mengembangkan BUMDesa". Pasal 87 ayat (2): "Pengembangan BUMDesa sebagaimana dimaksud pada ayat (1) dilakukan dengan: a. memberikan hibah dan/atau akses permodalan; b. melakukan pendampingan teknis dan akses ke pasar; dan c. memprioritaskan BUMDesa dalam pengelolaan sumber daya alam di Desa".

Pasal 81 ayat (1): "Pembangunan Desa bertujuan meningkatkan kesejahteraan masyarakat Desa dan kualitas hidup manusia serta penanggulangan kemiskinan melalui pemenuhan kebutuhan dasar, pembangunan sarana dan prasarana Desa, pengembangan potensi ekonomi lokal, serta pemanfaatan sumber daya alam dan lingkungan secara berkelanjutan. Pasal 81 ayat (2): "Pembangunan Desa sebagaimana dimaksud pada ayat (1) dilaksanakan dengan mengedepankan kebersamaan, kekeluargaan, dan kegotongroyongan guna mewujudkan 
pengarusutamaan perdamaian dan keadilan sosial. Pasal 81 ayat (3): "Pelaksanaan Pembangunan Desa sebagaimana dimaksud pada ayat (1) dilakukan dengan memanfaatkan kearifan lokal dan sumber daya alam Desa". Pasal 81 ayat (4): "Pengelolaan sumberdaya alam desa sebagaimana dimaksud pada ayat (2) dilakukan untuk meningkatkan kesejahteraan dan taraf hidup masyarakat Desa serta meningkatkan pendapatan Desa".

Pasal 87 ayat (1): "Rencana investasi masuk Desa dilakukan dengan cara membangun kerjasama desa dengan pihak ketiga untuk mengembangkan BUMDesa. Pasal 87 ayat (2): “Pengembangan BUMDesa sebagaimana dimaksud pada ayat (1) dilakukan dengan: a. memberikan hibah dan/atau akses permodalan; b. melakukan pendampingan teknis dan akses ke pasar; dan c. memprioritaskan BUMDesa dalam pengelolaan sumber daya alam di Desa".

Pasal 88 ayat (1): "Desa dapat mendirikan Badan Usaha Milik Desa yang disebut BUMDesa. Pasal 88 ayat (2): "Pendirian BUMDesa sebagaimana dimaksud pada ayat (1) disepakati melalui Musyawarah Desa". Pasal 88 ayat (3): "Hasil kesepakatan Musyawarah Desa sebagaimana dimaksud pada ayat (2) menjadi pedoman bagi Pemerintah Desa dan Badan Permusyawaratan Desa untuk menetapkan Peraturan Desa tentang Pendirian BUMDesa". Pasal 89 ayat (1): "Pokok bahasan yang dibicarakan dalam Musyawarah Desa sebagaimana dimaksud dalam Pasal 88 ayat (2) meliputi: a. organisasi pengelola BUMDesa; $b$. modal usaha BUMDesa; dan c. Anggaran Dasar dan Anggaran Rumah Tangga BUMDesa".

Kedelapan, Permendes PDTT Nomor 4 Tahun 2015 tentang Pendirian, Pengurusan dan Pengelolaan, dan Pembubaran Badan Usaha Milik Desa. Pasal 4 ayat (1): "Desa dapat mendirikan BUMDesa berdasarkan Peraturan Desa tentang Pendirian BUMDesa. Pasal 4 ayat (2): "Desa dapat mendirikan BUMDesa sebagaimana dimaksud pada ayat (1) dengan mempertimbangkan: a. inisiatif Pemerintah Desa dan/atau masyarakat Desa; b. potensi usaha ekonomi Desa; c. sumberdaya alam di Desa; d. sumberdaya manusia yang mampu mengelola BUMDesa; dan e. penyertaan modal dari Pemerintah Desa dalam bentuk pembiayaan dan kekayaan Desa yang diserahkan untuk dikelola sebagai bagian dari usaha BUMDesa".

Pasal 6 ayat (1): "Dalam rangka kerjasama antar Desa dan pelayanan usaha antar Desa dapat dibentuk BUM Desa bersama yang merupakan milik 2 (dua) Desa atau lebih". Pasal 6 ayat (2): "Pendirian BUMDesa bersama sebagaimana dimaksud pada ayat (1) disepakati melalui Musyawarah antar Desa yang difasilitasi oleh badan kerjasama antar Desa yang terdiri dari: a. Pemerintah Desa; b. anggota Badan Permusyawaratan Desa; c. lembaga kemasyarakatan Desa; d. lembaga Desa lainnya; dan e. tokoh masyarakat dengan mempertimbangkan keadilan gender".

Pasal 6 ayat (3): "Ketentuan mengenai Musyawarah Desa sebagaimana dimaksud dalam Pasal 5 berlaku secara mutatis mutandis terhadap pendirian BUMDesa bersama. Pasal 6 ayat (4): "BUMDesa bersama ditetapkan dalam Peraturan Bersama Kepala Desa tentang Pendirian BUMDesa bersama".

Terkait dengan Pasal 8: "BUMDesa dapat membentuk unit usaha meliputi: a. Perseroan Terbatas sebagai persekutuan modal, dibentuk berdasarkan perjanjian, dan melakukan kegiatan usaha dengan modal yang sebagian besar dimiliki oleh BUMDesa, sesuai dengan peraturan perundang-undangan tentang Perseroan Terbatas; dan b. Lembaga Keuangan 
Mikro dengan andil BUMDesa sebesar 60 (enam puluh) persen, sesuai dengan peraturan perundang-undangan tentang lembaga keuangan mikro".

Pasal 17 ayat (1): "Modal awal BUMDesa bersumber dari APBDesa. Pasal 17 ayat (2): "Modal BUMDesa terdiri atas: a. penyertaan modal Desa; dan b. penyertaan modal masyarakat Desa. Dan Pasal 18 ayat (1): "Penyertaan modal Desa sebagaimana dimaksud dalam Pasal 17 ayat (2) huruf a terdiri atas: a) hibah dari pihak swasta, lembaga sosial ekonomi kemasyarakatan dan/atau lembaga donor yang disalurkan melalui mekanisme APB Desa; b) bantuan Pemerintah, Pemerintah Daerah Provinsi, dan Pemerintah Daerah Kabupaten/ Kota yang disalurkan melalui mekanisme APB Desa; c) kerjasama usaha dari pihak swasta, lembaga sosial ekonomi kemasyarakatan dan/ atau lembaga donor yang dipastikan sebagai kekayaan kolektif Desa dan disalurkan melalui mekanisme APBDesa; dan d) aset Desa yang diserahkan kepada APBDesa sesuai dengan ketentuan peraturan perundang-undangan tentang Aset Desa".

Pasal 18 ayat (2): "Penyertaan modal masyarakat Desa sebagaimana dimaksud dalam Pasal 17 ayat (2) huruf b berasal dari tabungan masyarakat dan atau simpanan masyarakat". Selanjutnya Pasal 32 ayat (1): "Menteri menetapkan norma, standar, prosedur dan kriteria BUM Desa". Pasal 32 ayat (2): "Gubernur melakukan sosialisasi, bimbingan teknis tentang standar, prosedur, dan kriteria pengelolaan serta memfasilitasi akselerasi pengembangan modal dan pembinaan manajemen BUMDesa di Provinsi". Pasal 32 ayat (3): "Bupati/Walikota melakukan pembinaan, pemantauan dan evaluasi terhadap pengembangan manajemen dan sumber daya manusia pengelola BUMDesa".

\section{Pengelolaan Sumber Daya Alam Skala Desa oleh BUMDes Dalam Mewujudkan Masyarakat Desa}

Pengelolaan sumber daya alam skala desa secara normatif memang telah dijamin dalam berbagai peraturan perundang-undangan di Indonesia, yang antara lain dalam Pasal 33 ayat (3) UUD 1945, UU Nomor 23 Tahun 2014 tentang Pemerintahan Daerah, UU Nomor 6 Tahun 2014 tentang Desa, UU Nomor 41 Tahun 1999 tentang Kehutanan sebagaimana telah diubah dengan UU Nomor 19 Tahun 2004 tentang Penetapan Peraturan Pemerintah Penganti UU Nomor 1 Tahun 2004 tentang Perubahan Atas UU Nomor 41 Tahun 1999 tentang Kehutanan Menjadi Undang-Undang.

Selanjutnya pengaturan mengenai pengelolaan sumber daya alam skala desa oleh BUMDes, juga telah diatur dalam bertbagai peraturan perundang-undangan antara lain dalam UU Nomor 6 Tahun 2014 tentang Desa, PP Nomor 43 tahun 2014 tentang Peraturan Pelaksanaan UU Desa sebagaimana telah diubah dengan PP Nomor 47 Tahun 2015 tentang Perubahan Atas Peraturan Pemerintah Nomor 43 Tahun 2014 tentang Peraturan Pelaksanaan Undang-Undang Nomor 6 Tahun 2014 tentang Desa, Perpres Nomor 12 Tahun 2015 tentang Kementerian Desa, PDT, dan Transmigrasi, Permendagri Nomor 114 Tahun 2014 tentang Pedoman Pembangunan Desa, Permendes PDTT Nomor 1 Tahun 2015 tentang Pedoman Kewenangan Berdasarkan Hak Asal-Usul dan Kewenangan Lokal Berskala Desa, Permendes PDTT Nomor 2 Tahun 2015 tentang Pedoman Tata Tertib dan Mekanisme Pengambilan Keputusan Musyawarah Desa, Permendes PDTT Nomor 4 Tahun 2015 tentang Pendirian, 
Pengurusan dan pengelolaan, dan pembubaran Badan Usaha Milik Desa.

Berdasarkan berbagai peraturan perundangundangan tersebut di atas dapat disimpulkan bahwa secara normatif masyarakat desa memang mempunyai hak atas pengelolaan sumber daya alam skala desa dalam rangka mewujudkan kesejahteraan masyarakat desa yang salah satunya dapat dilakukan oleh BUMDes. Meskipun secara normatif pengelolaan sumber daya alam skala desa oleh BUMDes tersebut mempunyai dasar hukum yang kuat, namun dalam praktiknya masih terdapat permasalahan di lapangan dalam pelaksanaannya, antara lain disebabkan oleh hal-hal sebagai berikut:

a. Masih belum semua desa dapat menggali potensi sumber daya alamnya, sehingga hanya desa-desa yang sangat inovatif saja yang dapat mengelola potensi sumber daya alam skala desa seperti yang terdapat di Kabupaten Gunung Kidul yang sudah mempraktikkan pengelolaan sumber daya alam skala desa oleh BUMDes. Beberapa desa di Kabupaten Gunung Kidul yang sangat inovatif dan telah mempraktikkan pengelolaan sumber daya alam oleh BUMDes antara lain: Desa Mulo, Desa Karangrejek, Desa Duwet, Desa Wareng, Desa Karangtengah. Kelima desa tersebut mengelola potensi sumber daya alam yang berbeda-beda sesuai potensi sumber daya alam di masing-masing desa. BUMDes Desa Karangrejek mengelola beberapa potensi sumber daya alam antara lain: pertanian, tambang batu putih, sumber air bawah tanah dan sungai/air permukaan, jalur wisata. Selanjutnya BUMDes Desa Mulo mengelola sumber daya alam antara lain: batu karst, sumber air (embung), dan juga kawasan hutan. Sedangkan BUMDes Desa Duwet, mengelola sumber daya alam berupa sumber daya air untuk wisata air dan juga lahan pertanian seperti jagung, singkong, ubi dan juga padi gogo. Adapun BUMDes Desa Wareng hanya mengelola sumber daya alam air dan juga sumber daya alam pertanian. Kemudian yang terakhir BUMDes Desa Karangtengah mengelola wisata sungai, sentra kerajinan pandai besi, dan juga potensi objek wisata seperti gua bening, gua pari.

b. Masih belum optimalnya pembinaan yang dilakukan oleh Pemerintah Daerah Kabupaten/Kota yang hingga saat ini masih banyak yang belum membuat Perda terkait BUMDes yang merupakan amanat UU No. 6 Tahun 2014 tentang Desa, khususnya yang mengatur tentang pembinaan dan evaluasi terkait penggunaan dana desa sebagai modal awal bagi BUMDes. Belum optimalnya pembinaan oleh Pemerintah Daerah Kabupaten/Kota dapat ditunjukkan bahwa masih banyak Pemerintah Daerah Kabupaten/Kota yang sudah menindaklanjuti amanat UU Desa tersebut dengan berbagai Peraturan Daerah. Dari jumlah Kabupaten/ Kotamadya yang ada di Indonesia di masingmasing provinsi yang sudah menindaklanjuti dengan membuat Peraturan Daerah secara persentase baru sekitar kurang dari 30\% dari jumlah kabupaten/kotamadya yang ada di seluruh wilayah Indonesia. Hal ini menyebabkan pembinaan dan evaluasi terkait penggunaan dana desa sebagai modal BUMDes belum berjalan dengan baik sebagaimana mestinya.

c. Tingkat pengetahuan dan pemahaman Kepala Desa dan perangkat desa, terhadap kewenangan desa dalam pengelolaan 
sumber daya alam skala desa yang bertujuan untuk kepentingan kesejahteraan masyarakat desa juga menjadi kendala tersendiri, terutama ketika penyusunan Rencana Pembangunan Jangka Menengah Desa terkait pemanfaatan dana desa yang seringkali bukan dalam rangka mendukung pembentukan BUMDes.

d. Masih terdapat tumpang tindih peraturan perundang-undangan terkait kewenangan desa dalam pengelolaan sumber daya alam skala desa oleh BUMDes dalam beberapa peraturan teknis terutama antara Perda Kabupaten/Kota dengan peraturan perundang-undangan yang lebih tinggi seperti Peraturan Menteri dan juga tumpang tindih kewenangan dalam pembinaan dan evaluasi di daerah mengingat adanya perubahan nomenklatur kelembagaan di daerah Kabupaten/Kota.

e. Pengelolaan sumber daya alam oleh swasta baik nasional maupun modal asing di berbagai wilayah desa seperti di Kalimantan, Sulawesi, Sumatera, Papua dan wilayah Indonesia lainnya juga dirasakan masih menjadi permasalahan pengelolaan sumber daya alam skala desa oleh BUMDes, karena seringkali pola kemitraan yang dijadikan sebagai kebijakan oleh Pemerintah agar swasta bekerjasama dengan BUMDes di wilayah administratif sumber daya alam tersebut berada, tidak diikuti dengan praktik pelaksanaannya di lapangan.

Permasalahan-permasalahan tersebut di atas menyebabkan pengelolaan sumber daya alam skala desa oleh BUMDes belum dapat berjalan optimal sesuai tujuannya yaitu untuk menyejahterakan masyarakat desa. Oleh karenanya diperlukan langkah-langkah strategis sebagai solusi untuk mengatasi permasalahan tersebut di atas, antara lain:

a. Perlu dilakukan pelatihan-pelatihan yang lebih intensif oleh Kementerian terkait dan Pemerintah Daerah kepada masyarakat desa dan juga pemerintahan desa agar dapat lebih menggali potensi sumber daya alam skala desa, termasuk juga model pengelolaan sumber daya alam skala desa oleh BUMDes.

b. Perlu sosialisasi dan evaluasi dari Kementerian terkait terhadap dukungan Pemerintah Daerah dalam melakukan pembinaan dan evaluasi pembentukan BUMDes yang diwujudkan dengan pembentukan Perda tentang BUMDes.

c. Perlu dilakukan harmonisasi peraturan perundang-undangan di tingkat Peraturan Menteri dengan Perda, terkait dengan kewenangan desa dalam pengelolaan sumber daya alam skala desa oleh BUMDes.

d. Perluadanya dukungankebijakan Pemerintah dalam bentuk regulasi di tingkat Peraturan Menteri terutama dalam implementasi pelaksanaan Corporate Social Responsibility (CSR) dengan senantiasa melibatkan BUMDes dalam setiap pengelolan sumber daya alam oleh swasta/BUMN di desa.

Dengan adanya langkah-langkah tersebut diharapkan tujuan pengelolaan sumber daya alam skala desa oleh BUMDes dapat benarbenar mewujudkan kesejahteraan masyarakat desa. Sehingga amanat Pasal 33 ayat (3) UUD 1945 , yang pada intinya kekayaan alam yang berada di wilayah Indonesia, khususnya di desa dapat secara adil dan merata dipergunakan untuk menyejahterakan masyarakat desa. 


\section{Penutup}

Bahwa pengelolaan sumber daya alam skala desa telah diberikan landasan yuridis dalam UU Nomor 6 Tahun 2014 tentang Desa, khususnya diatur dalam Pasal 18 dan Pasal 19. Hal tersebut juga ditegaskan kembali dalam Pasal 371 ayat (2) UU Nomor 23 Tahun 2014 tentang Pemerintahan Daerah sebagaimana telah diubah dengan UU Nomor 2 Tahun 2015 tentang Perubahan Atas UU Nomor 23 Tahun 2014 tentang Pemerintahan Daerah. Dan peranan hukum dalam pengelolaan sumber daya alam skala desa oleh BUMDesa dalam rangka meningkatkan kesejahteraan masyarakat di desa, diwujudkan dengan adanya pengaturan dalam berbagai peraturan perundang-undangan sebagai berikut: UU Nomor 6 Tahun 2014 tentang Desa, UU Nomor 23 Tahun 2014 tentang Pemerintahan Daerah, UU Nomor 41 Tahun 1999 tentang Kehutanan, UU Nomor 39 Tahun 2014 tentang Perkebunan, PP Nomor 43 Tahun 2014 jo. PP No. 45 Tahun 2015, Perpres No. 2 Tahun 2015 tentang RPJM 2015-2019, Peraturan Menteri Desa, Percepatan Pembangunan Daerah Tertinggal dan Transmigrasi.

Konsep pengelolaan BUMDesa sesuai tujuan nasional prinsip keadilan sosial dalam meningkatkan kesejahteraan masyarakat desa sesuai dengan konsep sebagaimana diatur dalam ketentuan Pasal 33 ayat (3) UUD 1945. Konsep pengelolaan sumber daya alam skala desa sebagaimana dimaksud dalam prinsip keadilan sosial, sejalan dan sesuai dengan sila kelima Pancasila yaitu "keadilan sosial bagi seluruh rakyat Indonesia." Konsep pengelolaan sumber daya alam skala desa oleh BUMDesa tersebut secara eksplisit memang telah dilaksanakan oleh peraturan perundangundangan terkait seperti UU Desa, Peraturan Pemerintah sebagai pelaksanaan UU Desa dan juga sebagaimana diatur dalam berbagai peraturan menteri teknis sebagai pelaksanaan kedua jenis peraturan perundang-undangan tersebut, namun demikian pada kenyataannya masih perlu dilakukan pengawasan oleh pihak-pihak terkait sesuai kewenangan baik Pemerintah Pusat maupun Pemerintah Daerah, sehingga tidak terjadi tumpang tindih kewenangan yang mengakibatkan pelaksanaan hak desa atas sumber daya alam skala desa benar-benar dapat mewujudkan kesejahteraan masyarakat sebagaimana amanat Pasal 33 ayat (3) UUD 1945.

Oleh sebab itu perlu diatur ketentuan peraturan teknis untuk melakukan monitoring dan evaluasi terhadap pelaksanaan kewenangan dalam pembentukan dan pelaksanaan BUMDesa untuk mengelola sumber daya alam skala desa dan perlu dilakukan pengawasan dan pembinaan secara lebih fokus baik di tingkat provinsi maupun di tingkat kabupaten/kota terhadap pelaksanaan pengelolaan sumber daya alam skala desa oleh BUMDesa.

\section{Daftar Pustaka}

\section{Buku}

Badan Pusat Statistik, Kabupaten Gunung Kidul Dalam Angka 2016 (Yogyakarta: BPS Kab. Gunung Kidul, 2016)

Eko, Sutoro, Desa Membangun Indonesia (Yogyakarta: FPPD, 2014)

Kurniawan, Boni, Desa Mandiri, Desa Membangun (Jakarta: Kementerian Desa, Pembangunan Daerah Tertinggal, dan Transmigrasi Republik Indonesia, 2015)

Sutedi, Adrian, Implementasi Prinsip Kepentingan Umum Dalam Pengadaan Tanah Untuk Kepentingan Pembangunan (Jakarta: Sinar Grafika, 2008)

\section{Makalah/Artikel/Laporan/Hasil Penelitian}

Alains, dkk, "Pengelolaan Sumberdaya Perikanan Berbasis Masyarakat Melalui Model Co- 
Management Perikanan", Jurnal Ekonomi Pembangunan Vol. 10, No. 2 (2009)

Erwiningsih, Winahyu, "Peranan Hukum Dalam Pertanggungjawaban Perbuatan Pemerintahan (Suatu Kajian Kebijakan Pembangunan Hukum)", Jurnal Ilmu Hukum, Vol. 9, No. 2 (2006)

Karsidi, Ravik, "Paradigma Baru Penyuluhan Pembangunan Dalam Pemberdayaan Masyarakat", MediaTor Vol. 2, No. 1 (2001)

Pasandran, Effendi, "Pengelolaan Infrastruktur Irigasi Dalam Kerangka Ketahanan Pangan Nasional", Analisis Kebijakan Pertanian Vol. 5, No. 2 (2007) Pranadji, Tri, "Kerangka Kebijakan Sosio-Budaya Menuju Pertanian 2025, Kearah Pertanian Pedesaan Berdaya Saing Tinggi, Berkeadilan dan Berkelanjutan", Forum Penelitian Agro Ekonomi Vol. 22, No. 1 (2014)

Santoso, Urip, "Perolehan Tanah Oleh Pemerintah Daerah yang Berasal Dari Tanah Hak Milik", Jurnal Perspektif Vol. XX, No. 1 (2015)
Sidik, Fajar, "Menggali Potensi Lokal Mewujudkan Kemandirian Desa", Jurnal Kebijakan dan Administrasi Publik (JKAP), Vol. 19, No. 2 (2015)

Susanto, Bambang, dkk, "Perkembangan Kebijakan Pembiayaan Infrastruktur Transportasi Berbasis Kerjasama Pemerintah Swasta di Indonesia", Jurnal Transportasi Vol. 12, No. 2 (2012)

\section{Internet}

Kompas.com, "Dana Desa Cair April Menteri Desa Ingatkan Pentingnya BUMDesa", http://nasional. kompas.com/read/2015, (diakses Juli 2017)

\section{Peraturan}

Undang-Undang Nomor 6 Tahun 2014 tentang Desa. Undang-Undang Nomor 23 Tahun 2014 tentang Pemerintahan Daerah. 